\title{
PERSEPSI PETANI DALAM MEMASARKAN BOKAR (BAHAN OLAHAN KARET) DI DESA PONDOK MEJA KECAMATAN MESTONG
}

\author{
Indra Febriyanto ${ }^{1}$, Idris Sardi ${ }^{2}$ dan Emy Kernalis ${ }^{2}$
}

1) Alumni Program Studi Agribisnis Fakultas Pertanian Universitas Jambi,

2) Staf Pengajar Program Studi Agribisnis Fakultas Pertanian Universitas Jambi

Email : indrafry@yahoo.com.id

\begin{abstract}
The purpose of this study to determine the perception of rubber farmers in the market if the rubber material in the village cottage Desk, in marketing if the rubber material is limited by two aspects: economy concerning the perception of farmers on the price of rubber or high if it sell to traders. Farmers in marketing material aspect of this economy if its rubber which is more profitable for them, the second is the social aspect, the social aspect concerns the perception of farmers in the ease of marketing material and emotional closeness if farmers against the trader. The research was conducted in the village Pondok Meja by using a sample of 40 farmers, which consists of farmers who sell the material if its rubber to 20 farmer cooperatives and farmers who sell the material if its rubber to a collector for 20 farmers. Selection of study sites was done intentionally (purposive) based on that village Pondok Meja has the largest rubber plantation in District Mestong Muaro Jambi. The data obtained in the field though in terms of the number and percentage then tabulated and analyzed descriptively further. The results of the study concluded that (1) the economic aspect is concluded that the majority of respondents perceive farmers market if the rubber material is more profitable and provide for their welfare. (2) From the social aspect is most farmers respondents perceive marketing materials to the trader if his rubber can still be profitable. Farmers perception in marketing material states that if the rubber to a collector for easier and faster.
\end{abstract}

Keywords : Perception, Marketing bokar

\section{ABSTRAK}

Tujuan penelitian ini untuk mengetahui persepsi petani karet dalam memasarkan bahan olah karet (bokar) di Desa Pondok Meja, dalam memasarkan bokar dibatasi oleh dua aspek yaitu aspek ekonomi yang menyangkut persepsi petani terhadap harga bokar atau tingginya jual bokar ke pedagang. Persepsi petani dalam aspek ekonomi ini memasarkan bokarnya mana yang lebih menguntungkan bagi mereka. Yang kedua yaitu aspek sosial, aspek sosial menyangkut persepsi petani dalam kemudahan memasarkan bokar serta kedekatan emosional petani terhadap pedagang tersebut. Penelitian ini dilaksanakan di Desa Pondok Meja dengan mengggunakan 40 petani sampel, yang terdiri dari petani yang menjual bokarnya kepada koperasi 20 petani dan petani yang menjual bokarnya kepada pedagang pengumpul 20 petani. Pemilihan lokasi penelitian ini dilakukan secara sengaja (purposive) berdasarkan bahwa Desa Pondok Meja mempunyai perkebunan karet terluas di Kecamatan Mestong Kabupaten Muaro Jambi. Data yang diperoleh dilapangan di olah dalam bentuk jumlah dan persentase kemudian ditabulasikan dan selanjutnya dianalisis secara deskriptif. Hasil penelitian disimpulkan bahwa (1) Dari aspek ekonomi diperoleh kesimpulan sebagian besar petani yang menjadi responden mempersepsikan memasarkan bokar lebih menguntungkan dan memberi kesejahteraan bagi mereka. Petani responden yang cekatan lebih dapat memberi kesejahteraan bagi mereka dan keluarganya, (2) Dari aspek sosial ini sebagian besar petani responden mempersepsikan memasarkan bokarnya kepada pedagang masih bisa menguntungkan. Persepsi Petani menyatakan bahwa dalam memasarkan bokar kepada pedagang pengumpul lebih mudah dan cepat. 
Kata Kunci : Persepsi, Memasarkan bokar

\section{PENDAHULUAN}

Kabupaten Muaro Jambi mempunyai luas pengusahaan tanaman karet yang di dominasi oleh perkebunan rakyat. Salah satu kecamatan yang mengusahakan tanaman karet di Kabupaten Muaro Jambi ialah Kecamatan Mestong. Kecamatan Mestong memiliki luas area tanaman perkebunan karet rakyat terbesar kedua terbesar setelah Kecamatan Sakernan dengan luas area 14.597 hektar, dibandingkan Kecamatan Sakernan yang mencapai 15.977 hektar. Kecamatan Sakernan menghasilkan produksi sebanyak 9.558 ton dengan jumlah petani sebanyak 4618 KK. Bila dibandingkan Kecamatan Mestong yang menghasilkan karet sebasar 6.222 ton dengan jumlah petani yaitu 2.663 KK (Dinas Perkebunan Provinsi Jambi, 2013), dengan jumlah petani kurang lebih setengah dari jumlah petani di Kecamatan Sekernan petani karet di Kecamatan Mestong mampu menghasilkan produksi karet hampir mendekati produksi karet Kecamatan Sakernan. Hal ini menunjukkan besarnya potensi sumber daya manusia dari petani karet yang mampu menekan jumlah tenaga kerja sehingga petani tidak perlu mengeluarkan biaya yang besar.

Pada Kecamatan Mestong, Desa Pondok Meja merupakan desa yang paling banyak luas lahan perkebunan karet mencapai 1657 hektar dengan produksi karet sebanyak 259,35 ton (Dinas Perkebunan Provinsi Jambi, 2013). Produksi karet di Desa Pondok Meja yang sebanyak 259,35 ton per tahunnya tentu perlu adanya sistem pemasaran yang menguntungkan untuk petani agar para petani karet mendapatkan keuntungan yang optimal. Dalam hal ini petani memasarkan bahan olah karet (bokar) tidak hanya tergantung pada satu saluran pemasaran saja. Tapi petani memiliki persepsi yang berbeda dalam memasarkan bahan olah karet.

Persepsi mempunyai pengertian yaitu suatu proses seseorang untuk mengetahui, menginterprestasikan dan mengevaluasi orang lain yang dipersepsi, tentang sifatsifatnya, kualitasnya dan keadaan yang lain yang ada dalam diri orang yang dipersepsi, sehingga terbentuk gambaran mengenai orang yang dipersepsi (Van De Ban, 2008). Namun demikian karena yang dipersepsi itu manusia seperti halnya dengan yang mempersepsi, maka objek persepsi dapat memberikan pengaruh kepada yang mempersepsi. Persepsi petani dalam memasarkan bokar terdiri dari beberapa aspek diantaranya dari segi untung rugi dan segi kesejahteraan, (1) Segi kesejahteraan meliputi aspek-aspek sosial yaitu ; kedekatan emosional, kenyamanan, kepercayaan, kepekaan sosial, kemandirian dll. (2) segi untung rugi meliputi aspek-aspek ekonomi yaitu ; pendapatan, keuntungan dan penerimaan dll. Dengan demikian dapat dikemukakan dalam mempersepsi manusia atau orang (person) adanya dua pihak yang masing-masing mempunyai kemampuan - kemampuan, perasaan-perasaan, harapan - harapan, pengalaman - pengalaman tertentu yang berbeda satu dengan yang lain, yang akan dapat berpengaruh dalam mempersepsi manusia atau orang tersebut. Sehingga dalam hal ini petani memiliki persepsi dalam memasarkan bokarnya dalam berbagai bentuk saluran pemasaran, yaitu menjual ke pedagang pengumpul (petani - pedagang pengumpul - konsumen) dan ada juga yang bukan ke pedagang pengumpul desa, dalam hal ini ialah memasarkan kepada koperasi (petani - koperasi - konsumen). Menurut Sunarto, (2003), pemasaran merupakan suatu proses sosial dan manajerial yang membuat individu dan kelompok memperoleh apa yang mereka butuhkan dan inginkan, lewat penciptan dan pertukaran timbal balik produk dan nilai dengan orang lain Pada tingkat desa yang paling berperan adalah pedagang pengumpul yang melaksanakan kegiatan pemasaran berkaitan dengan perantara ditingkat atas atau agen komisi. Selain 
itu berperan juga sebagai lembaga kredit informal yang dapat menolong petani pada saat kesulitan. Ikatan ini memberi dampak kepada petani yang mempengaruhi harga terutama dari pihak pedagang. Peminjaman yang dilakukan oleh petani kepada pedagang pengumpul memberikan dampak kepada petani, sehingga petani sering berada di posisi yang lemah dalam penentu harga. Peminjaman yang dilakukan oleh petani kepada pedagang pengumpul terus berlangsung dalam kekeluargaan, keadaan kekerabatan ini dimanfaatkan oleh pedagang untuk lebih mudah mengikat petani.

Selain kepada pedagang pengumpul, petani biasa juga memasarkan bokar ke koperasi yang ada di desa, tentunya di koperasi petani tidak terjebak permainan pedagang pengumpul. Koperasi di kelola oleh sesama petani sehingga informasi tentang perubahan harga kepada petani diberlakukan sebagimana mestinya. Informasi perubahan harga kepada petani dapat disalurkan melalui koperasi. Sehingga petani tidak dirugikan bila terjadi kenaikan bahkan penurunan harga jual bokar.

Sebagian petani karet menjual bokar berdasarkan berat bokar bukan berdasarkan mutu bokar. Petani yang menjual bokarnya hanya berdasarkan beratnya akan melakukan perendaman karet dalam air, seperti sungai, rawa dan lainnya. Sistem perendaman produksi karet tersebut yang menyebabkan rendahnya mutu karet. Biasanya petani yang seperti itu akan menjual produksi karetnya pada pedagang pengumpul di desa dengan tingkat harga yang rendah. Pedagang pengumpul desa memiliki kelebihan yaitu petani bisa menjual kapan saja bokarnya, pedagang pengumpul desa dapat memberikan bantuan berupa pinjaman alat produksi atau dana kepada petani sebelum petani menjual bokarnya. Sedangkan kekurangan pedagang pengumpul desa terletak pada informasi harga yang tidak transparan, pedagang pengumpul desa membeli bokar dengan harga rendah dan adanya potongan harga dan potongan timbangan yang biasa disebut dengan basi atau penyusutan.

Desa Pondok Meja memiliki luas perkebunan karet terluas di Kecamatan mestong dengan luas 1657 hektar dan mempunyai produksi karet sebanyak 259,35 Ton per tahun (Balai Penyuluhan Pertanian, 2013). Dengan produksi yang dihasilkan sebanyak 259,35 ton per tahun tentunya petani memiliki persepsi dalam memasarkan hasil bahan olah karet meraka, yaitu memasarkan ke pedagang pengumpul atau ke koperasi. Persepsi memiliki pengertian sebagai suatu proses seseorang untuk mengetahui, menginterprestasikan dan mengevaluasi orang lain yang dipersepsi, tentang sifat-sifatnya, kualitasnya dan keadaan yang lain yang ada dalam diri orang yang dipersepsi, sehingga terbentuk gambaran mengenai orang yang dipersepsi. Hal ini berarti persepsi petani adalah merupakan kemampuan petani dalam menerima stimulus dari lingkungan sekitarnya dalam memasarkan hasil bokarnya yang akan terwujud dalam memilih antara memasarkan kepedagang pengumpul dalam hal ini ialah pedagang pengumpul dan koperasi. Adapun tujuan penelitian ini adalah untuk mengetahui persepsi petani dalam memasarkan bahan olah karet (Bokar) di Desa pondok Meja, sehingga persepsi petani ini nantinya akan mempengaruhi pendapatan yang mereka peroleh karena antara memasarkan ke pedagang pengumpul dan memasarkan ke koperasi memiliki perbedaan harga jual bahan olah karet

\section{METODE PENELITIAN}

Penelitian ini dilaksanakan di Desa Pondok Meja Kecamatan Mestong Kabupaten Muaro Jambi. Pemilihan lokasi penelitian ini dilakukan secara sengaja (purposive) berdasarkan bahwa Desa Pondok Meja mempunyai perkebunan karet terluas di Kecamatan Mestong Kabupaten Muaro Jambi. Selain itu sebagian besar mata 
pencaharian masyarakat bersumber dari karet. Adapun yang menjadi objek dalam penelitian ini adalah petani karet yang menjual hasil bokar. Penelitian ini dilaksanakan pada bulan mei sampai dengan bulan juni.

Metode pengumpulan data yang digunakan dalam penelitian ini terdiri dari data primer dan data sekunder. Data primer diperoleh dari hasil wawancara langsung dengan petani yang dituntun dengan kuisioner yang telah dipersiapkan lebih dahulu. Sedangkan data sekunder diperoleh dari dinas atau instansi yang terkait dengan penelitian ini. Kemudian untuk melengkapi informasi data yang diperlukan diperoleh dari sumbersumber lain serta literatur yang berhubungan dengan penelitian.

Dari lima belas desa yang ada di Kecamatan Mestong di ambil satu desa secara sengaja sebagai lokasi penelitian yaitu Desa Pondok Meja. Adapun pemilihan desa tersebut sebagai desa sampel dengan pertimbangan bahwa desa tersebut mempunyai luas lahan perkebunan karet terluas di Kecamatan Mestong.

Pengambilan sampel petani mengunakan metode acak sederhana (Simple Ramdom Sampling) dengan pertimbangan bahwa desa tersebut terdapat petani yang menjual bokar baik kepada pedagang pengumpul desa maupun yang menjual kepada koperasi. Pengambilan petani sampel ini dilakukan melalui teknik metode acak sederhana dengan pengertian pemilihan sampel atau sejumlah elemen dari populasi dengan di undi sehingga setiap populasi mempunyai kesempatan yang sama untuk menjadi sampel (Singgarinbun dan Effendi, 1995). Diharapkan hasil yang diperoleh dapat menggambarkan sifat dari populasi tersebut.

Metode penarikan sampel yang digunakan dalam penelitian ini adalah dengan sengaja (purposive) dengan pertimbangan bahwa Desa Pondok Meja sebagai daerah yang memiliki jumlah petani karet terbesar di Kecamatan Mestong. Pengambilan sampel dalam penelitian ini didekati menggunakan metode simple random sampling. Jumlah sampel dalam penelitian ini ditentukan dengan menggunakan rumus dari Taro Yamane atau Slovin dalam Riduwan (2007) dengan pertimbangan menggunakan presisi sebesar 15 persen dari jumlah keseluruhan populasi petani karet di Desa Pondok Meja sebanyak 399. Dari perhitungan sampel dengan menggunakan rumus tersebut, maka diperoleh jumlah sebesar 40 petani sampel. Karena penelitian ini menggunakan analisis deskriptif dan persentase maka pengambilan sampel petani akan dilakukan secara acak untuk mengetahui persepsi petani dalam memasarkan bokarnya ke koperasi dan pedagang pengumpul, bagaimana persepsi petani dari 40 sampel tesebut.

Data yang diperoleh di lapangan di olah dalam bentuk jumlah dan persentase kemudian ditabulasikan dan selanjutnya di analisis secara deskriptif. Analisis deskriptif digunakan untuk melihat gambaran persepsi petani karet dalam memasarkan bokar di desa Pondok Meja Kecamatan Mestong Kabupaten Muaro Jambi.

\section{HASIL DAN PEMBAHASAN}

Dalam penelitian ini persepsi dalam memasarkan bokar dibatasi oleh beberapa aspek yang terdiri 2 yaitu segi untung rugi meliputi aspek-aspek ekonomi dan segi kesejahteraan yang meliputi aspek-aspek sosial. segi untung rugi yang menyangkut persepsi petani terhadap harga bokar atau tingginya jual bokar ke pedagang, persepsi petani dari aspek ekonomi ini memasarkan bokarnya mana yang lebih menguntungkan bagi mereka dan mana yg kurang menguntungkan bagi mereka. Yang ke dua yaitu dari segi kesejahteraan, dari segi kesejahteraan menyangkut persepsi petani dalam kemudahan memasarkan bokar serta kedekatan emosional petani terhadap pedagang tersebut. Aspek sosial berpengaruh terhadap petani karna kenyamanan dan keterbisaan 
petani dalam memasarkan bokarnya. Persepsi petani diperoleh dari petani bagaimana petani mempersepsikan pedagang untuk memasarkan bokarnya, apakah petani menilai positif menjual bokarnya kepada pedagang tersebut dapat lebih menguntungkan, dengan diketahuinya penilaian tersebut dapat diketahui keberlanjutan nya apakah petani bisa layak hidupnya untuk memakmuran keluarganya kedepan, masihkah petani terus membudidayakan karet untuk pendapatan mereka atau sebaliknya. proses kognitif diatas adalah proses kegiatan mental yang sadar seperti sikap, kepercayaan dan pengharapan yang semuanya merupakan faktor yang menetukan perilaku (Thoha, 2000). Berikut ini dapat kita lihat persepsi petani dalam memasarkan bokar di Desa Pondok Meja dilihat dari beberapa aspek persepsi pada Tabel 1.

Tabel 1. Persepsi Petani Dalam Memasarkan Bokar di Desa Pondok Meja dilihat dari Beberapa Aspek Persepsi Tahun 2014.

\begin{tabular}{lcccc}
\hline \multirow{2}{*}{\multicolumn{1}{c}{ Aspek }} & \multicolumn{2}{c}{ Koperasi } & \multicolumn{2}{c}{ Pedagang Pengumpul } \\
\cline { 2 - 5 } & 26 & 14 & 20 & 20 \\
\hline Lebih menguntungkan & 20 & 20 & 25 & 15 \\
Lebih mudah menjual & 31 & 9 & 14 & 26 \\
Jelas transparansi harga & 4 & 36 & 19 & 21 \\
Tidak sering berfultuasi & - & 40 & 40 & - \\
Tidak memberi persyaratan dalam & & & & \\
menjual & 20 & 20 & 27 & 13 \\
Lebih nyaman pelanyanannya & 30 & 10 & 18 & 22 \\
Lebih dipercaya & 12 & 28 & 33 & 7 \\
Memberikan pinjaman & 20 & 20 & 25 & 15 \\
Hubungan emosional & 20 & 20 & 25 & 15 \\
Lebih cepat saluran pemasarannya & 215 & 217 & 246 & 154 \\
\hline Jumlah & &
\end{tabular}

Sumber : Petani Responden Desa Pondok Meja Tahun 2014

Dari Tabel 18 dapat kita lihat bahwa petani responden memiliki persepsi yang beragam, dari beberapa aspek persepsi petani responden cendrung lebih tinggi terhadap pedagang pengumpul, walaupun mereka tahu bahwa koperasi jauh lebih tinggi dari segi harga bokar. Tetapi dibalik semua itu banyak aspek lain yang mempengaruhi banyak petani untuk tetap memilih pedagang pengumpul.

\section{Segi Untung Rugi}

Menurut Agus (2013) Aspek ekonomi adalah aspek eksternal pendapatan seseorang dalam memenuhi kebutuhan. Dalam melakukan usahatani, aspek ekonomi merupakan aspek penting yang perlu diperhatikan, hal ini dikarenakan berkaitan dengan penghasilan dan biaya-biaya yang dibutuhkan dalam pengelolaan usahataninya (Sunarto, 2003). Namun dalam penelitian aspek ekonomi dibatasi pada bagaimana usahatani karet ini kedepannya, apakah masih menguntungkan atau tidak. Sehingga dengan mengetahui persepsi petani tersebut petani dapat mengetahui keberlanjutan usahatani karet kedepannya. persepsi petani dalam memasarkan bokarnya ada dua tujuan yaitu kepada pedagang pengumpul dan koperasi. Aspek ekonomi sangat mempengaruhi persepsi petani dalam memasarkan bokarnya kepada pedagang, petani memilih mana yang lebih menguntungkan jika menjual kepedagang pengumpul atau ke koperasi.

Hasil penelitian terhadap keseluruhan petani responden yang berusahatani karet diperoleh 3 (tiga) persepsi petani terdahap pemasaran bokarnya kepada pedagang pengumpul dan koperasi dilihat dari aspek ekonomi, yaitu menguntungkan, tidak 
menguntungkan dan sama saja. Sebagian besar petani mempersepsikan menjual kepada koperasi lebih menguntungkan dari pada kepada pedagang pengumpul. Untuk lebih jelasnya bisa kita lihat persepsi petani kepada koperasi pada Tabel 2 berikut ini.

Tabel 2. Persepsi Petani Dalam Memasarkan Bokar Kepada Koperasi dan Pedagang Pengumpul Dari Aspek Ekonomi Dirinci Menurut Frekuensi dan Persentase Terhadap Jumlah Responden, Tahun 2014.

\begin{tabular}{lcc}
\hline \multicolumn{1}{c}{ Persepsi } & Frekuensi (KK) & Persentase (\%) \\
\hline Menjual kepada Koperasi & 20 & 50 \\
Mmnguntungkan & 14 & 35 \\
Menjual kepada Pedagang & & \\
Pengumpul menguntungkan & 6 & 15 \\
Sama-sama menguntungkan & 40 & 100 \\
\hline Jumlah &
\end{tabular}

Sumber : Petani Responden Desa Pondok Meja Tahun 2014

Petani yang mempersepsikan baik kepada koperasi dilihat dari aspek ekonomi yang melihat bahwa menjual kepada koperasi lebih menguntungkan yaitu mencapai 50 persen dari jumlah petani responden. Selain itu ada juga petani yang mempersepsikan menjual kepada Pedagang Pengumpul lebih menguntungkan yaitu sebesar 35 persen, dan sebagian responden lainnya mereka mempersepsikan bahwa menjual kepada koperasi dan pedagang pengumpul sama-sama menguntungkan yaitu sebesar 15 persen, hal ini dikarenakan petani beranggapan menjual bokar kepada koperasi dan pedagang pengumpul itu tergantung bagaimana kualitas bokar tersebut. pada saat ini harga bokar memang sedang turun dibandingkan harga bokar dari tahun-tahun sebelumnya, ini membuat petani karet semakin terpuruk keadaan ekonominya dari harga bokar yang sebelumnya berkisar Rp. 12.000 sampai Rp 14.000 kini harga jual bokar hanya sekitar Rp. 7000 sampai dengan Rp.9000 saja. Ini disebabkan karena harga karet dunia sedang anjlok. Dari segi aspek ekonomi kini harga bokar yang berkualitas baik yang dibeli oleh koperasi yaitu Rp. 9000 sedangkan harga bokar yang dibeli oleh pedagang pengumpul sekitar Rp.7000 sampai Rp.8000 saja untuk semua jenis bokar yang dijual oleh petani.

Dari Tabel 2 di atas dapat dilihat bahwa petani mempersepsikan pada koperasi lebih dominan positif dari aspek ekonomi mencapai 50 persen dari total responden. Ini terbukti bahwa koperasi baik dalam menetapkan harga beli bokar kepada petani. Sebagian Responden mempersepsikan bahwa menjual kepada pedagang pengumpul lebih menguntungkan dari aspek-aspek ekonomi.

Berdasarkan uraian diatas dari segi untung rugi tentang pemasaran bokar diperoleh 3 (tiga) persepsi yang dikatakan petani, dan selanjutnya dari setiap persepsi yang diungkapkan petani tentang pemasaran bokar dilihat dari segi untung rugi memiliki bermacam keragaman alasan yang berbeda-beda yang melatarbelakangi persepsi mereka kepada pedagang yang mereka pilih. Untuk melihat persentase alasan yang melatarbelakangi petani yang mempersepsikan menjual kepada koperasi lebih menguntungkan dari segi untung rugi dapat dilihat pada Tabel 3 berikut ini.

Tabel 3. Alasan Yang Melatarbelakangi Persepsi Petani Memasarkan Bokar Kepada Koperasi Lebih Menguntungkan Dari Segi Untung Rugi, Tahun 2014.

\begin{tabular}{lcc}
\hline \multicolumn{1}{c}{ Alasan } & Frekunsi (KK) & Persentase (\%) \\
\hline $\begin{array}{l}\text { Harganya Lebih Tinggi dari } \\
\text { pedagang pengumpul }\end{array}$ & 16 & 80 \\
Jujur dalam timbangan & 4 & 20 \\
\hline
\end{tabular}


\begin{tabular}{lll}
\hline Jumlah & 20 & 100
\end{tabular}

Sumber : Petani Responden Desa Pondok Meja Tahun 2014

Menurut Wahyuni (2004), koperasi unit desa adalah suatu organisasi ekonomi yang berwatak sosial dan merupakan pusat pelayanan kegiatan ekonomi di daerah pedesaan yang diselenggarakan oleh masyarakat dan untuk masyarakat itu sendiri dengan tujuan untuk meningkatkan kesejahteraan anggota masyarakat. Berdasarkan Tabel 3 di atas dapat diketahui alasan responden yang mempersepsikan koperasi lebih baik, rata-rata responden memberi alasan bahwa harga jual kepada koperasi lebih tinggi dari pada pedagang pengumpul, dan alasan yang melatar belakangi persepsi petani dalam memasarkan bokar dilihat dari aspek-aspek ekonomi bisa lebih menguntungkan serta jujur dalam melakukan timbangan pada bokar, dan sisa responden lain yang mempersepsikan koperasi baik memberi alasan dikoperasi harga bokar diberi tahu lebih jelas, dan juga ada ada yang memberi alasan bahwa mereka mendapatkan bantuan subsidi pupuk petani yang tergabung dalam anggota koperasi saja, selain itu koperasi juga dapat memberikan pinjaman berupa uang ataupun barang keperluan sehari-hari seperti sembako karena koperasi memiliki toko koperasi yang dikelola oleh ketua koperasinya. Petani yang ikut dalam kelompok tani sudah tentu mereka menjual kepada koperasi.

Untuk alasan petani yang melatar belakangi persepsi dari segi untung rugi menjual bokar kepada Pedagang Pengumpul lebih menguntungkan dapat dilihat pada Tabel 4 berikut ini.

Tabel 4. Alasan Yang Melatar Belakangi Persepsi Petani Dalam Memasarkan Bokar Kepada Pedagang Pengumpul Menguntungkan Dari Segi Untung Rugi, Tahun 2014.

\begin{tabular}{lcc}
\hline \multicolumn{1}{c}{ Alasan } & Frekuensi (KK) & Persentase (\%) \\
\hline $\begin{array}{l}\text { Proses menjual bokar lebih } \\
\text { cepat }\end{array}$ & 12 & 60 \\
$\begin{array}{l}\text { Tidak ada persyaratan kualitas } \\
\text { bokar, tidak memerlukan biaya } \\
\text { lebih. }\end{array}$ & 8 & 40 \\
\hline Jumlah & 20 & 100 \\
\hline
\end{tabular}

Sumber : Petani Responden Desa Pondok Meja Tahun 2014

Berdasarkan Tabel 4 di atas dapat diketahui rata-rata jawaban dari kuisioner petani responden mempersepsikan menjual bokar kepada Pedagang Pengumpul juga menguntungkan bila dilihat dari segi untung rugi. Menurut Arfandi dalam Ayu (2010) pedagang pengumpul merupakan lembaga ekonomi desa yang berdiri sendiri dan tidak memiliki badan hukum resmi, bebas beroperasi dan membeli ke petani secara langsung tanpa proses yang rumit. Petani responden mengatakan menguntungkan menjual kepada pedagang pengumpul memiliki 2 (dua) alasan yaitu : yang pertama proses menjual bokar lebih cepat karena pedagang pengumpul yang datang menghampiri petani untuk membeli bokarnya, pedagang pengumpul bisa dua sampai empat kali seminggu untuk datang membeli bokar kerumah petani langsung, sedangkan jika menjual bokar kepada koperasi petani responden memberi alasan mereka harus mengantar sendiri ke koperasi dan perlu biaya transportasi yang dikeluarkan, tidak ada dijemput seperti pedagang pengumpul. Dan alasan yang kedua petani responden mempersepsikan pedagang pengumpul lebih menguntungkan memberi alasan menjual bokar kepada pedagang pengumpul bokarnya tidak harus berkualitas baik, karena membuat bokar dengan kualitas baik akan memperlama dan sulit bagi mereka, serta 
membutuhkan biaya tambahan dalam membuat bokar yang bagus cuka yang dianjurkan lebih mahal, kadar karet putih lebih banyak, dan bokar yang telah jadi sleb harus digiling. Alasan lain dari petani menjawab karna mereka sudah terbiasa dan jelas harganya menjual kepada pedagang pengumpul.

Dalam budidaya setiap tanaman tentu tidak terlepas dengan muara yang dikenal dengan profit atau keuntungan. Untuk mencapai muara keuntungan tersebut tidak terlepas dari berbagai hal dan prosedur sesuai kaidah budidaya jenis tanaman yang diusahakan. Dalam budidaya suatu tanaman yang tidak kalah penting peranannya adalah bagaimana menyediakan unsur hara tanaman dalam keadaan tersedia dan berimbang. Sehingga tidak menimbulkan efek negative bagi pembudidaya dan hasil produksi yang dicapai memuaskan.

\section{Segi Kesejahteraan}

Menurut Agus (2013) persepsi dari aspek sosial yaitu objek yang berada dalam diri individu yang dipersepsi atau faktor internal yang dipersepsi. Aspek sosial/ jaminan hidup yang dimaksud dalam penelitian ini adalah bagaimana persepsi petani terhadap pemasaran bokar kepada koperasi dan pedagang pengumpul, apakah dari hasil perkebunan karet mereka dapat menjamin kehidupan dan memenuhi kebutuhan keluarga petani dan mendapat penghasilan yang lebih menjamin kepada petani dalam menjual bokarnya kepada koperasi atau pedagang pengumpul. Dalam mempersepsi manusia (person) adanya dua pihak yang masing-masing mempunyai kemampuankemampuan, perasaan-perasaan, harapan-harapan, pengalaman-pengalaman tertentu yang berbeda satu dengan yang lain, Sarwono (2002). Dengan diketahuinya persepsi tersebut maka dapat diketahui pula manakah yang lebih dapat mensejahterakan petani bila menjual bokarnya kepada koperasi atau pedagang pengumpul. Untuk lebih jelasnya dapat dilihat pada tabel berikut ini.

Tabel 5. Persepsi Petani Dalam Memasarkan Bokar Kepada Koperasi dan Pedagang Pengumpul dari Segi Kesejahteraan Dirinci Menurut Frekuensi dan Persentase Terhadap Jumlah Responden, Tahun 2014

\begin{tabular}{lcc}
\multicolumn{1}{c}{ Alasan } & Frekuensi (KK) & Persentase (\%) \\
\hline $\begin{array}{l}\text { Menjual kepada koperasi } \\
\text { kesejahteraan }\end{array}$ & 15 & 37,5 \\
$\begin{array}{l}\text { Menjual kepada pedagang pengumpul } \\
\text { menjamin kesejahteraan }\end{array}$ & 20 & 50 \\
Sama saja & 5 & 12,5 \\
\hline Jumlah & 40 & 100 \\
\hline Sumber : Petani Responden Desa Pondok Meja Tahun 2014
\end{tabular}

Berdasarkan Tabel 5 di atas dapat diketahui bahwa sebagian besar petani dari 40 sampel responden mempersepsikan menjual bokarnya kepada pedagang pengumpul dapat menjamin kesejahteraan dan masih dapat memenuhi kebutuhan mereka untuk keperluan sehari-hari dibandingkan menjual bokarnya kepada koperasi dari segi kesejahteraan. Untuk melihat persentase alasan yang melatarbelakangi petani yang mempersepsikan menjual kepada pedagang pengumpul masih bisa memperoleh keuntungan dari segi kesejahteraan dapat dilihat pada Tabel 6 berikut ini. 
Tabel 6. Alasan Yang Melatarbelakangi Persepsi Petani Dalam Memasarkan Bokar Kepada Pedagang Pengumpul Masih Bisa Memperoleh Keuntungan Dilihat Dari Segi Kesejahteraan.

\begin{tabular}{lcc}
\hline \multicolumn{1}{c}{ Alasan } & Frekuensi (KK) & Persentase (\%) \\
\hline $\begin{array}{l}\text { Proses lebih mudah jika ingin } \\
\text { menjual bokar }\end{array}$ & 17 & 85 \\
$\begin{array}{l}\text { Dapat memberi pinjaman berupa } \\
\text { uang atau keperluan sehari-hari }\end{array}$ & 3 & 15 \\
\hline Jumlah & 20 & 100
\end{tabular}

Sumber : Petani Responden Desa Pondok Meja Tahun 2014

Berdasarkan Tabel 6 di atas dapat diketahui petani responden dari keseluruhan responden yang mempersepsikan menjual bokar kepada Pedagang Pengumpul mereka masih dapat memperoleh keuntungan bila dilihat dari segi kesejahteraan. Ini disebabkan karena sebagian besar petani secara tidak sadar sudah membangun pola keterikatan kepada pedagang pengumpul dan menciptakan kenyamanan, Para responden mengatakan dapat menjamin kesejahteraan rata-rata mereka memiliki 2 (dua) alasan yaitu; yang pertama petani mempersepsikan pedagang pengumpul lebih memberi pelayanan yang baik dengan pendekatan langsung kepada petani, proses menjual bokarpun jadi lebih mudah. Kemudian yang kedua petani dapat minta pinjaman berupa uang atau barang keperluan sehari-hari kepada pedagang pengumpul. Alasan lain mengatakan karna mereka telah terbiasa dan kenal terhadap pedagang pengumpul Inilah alasan yang diperoleh dari responden tentang pedagang pengumpul.

Menjual bokar kepada koperasi apakah bisa memenuhi kebutuhan keluarga mereka agar lebih sejatera atau sama saja, padahal dari segi untung rugi harga jauh lebih tinggi bila menjual kepada koperasi dan dapat keuntungan lebih besar, mengapa bisa demikian terbalik dengan kesejahteraan yang diperoleh petani lebih dominan kepada pedagang pengumpul. Untuk alasan petani yang melatar belakangi persepsi dari segi kesejahteraan menjual bokar kepada koperasi lebih menjamin kesejahteraan dapat dilihat pada Tabel 7 berikut:

Tabel 24. Alasan Yang Melatarbelakangi Persepsi Petani Dalam Memasarkan Bokar Kepada Koperasi Masih Dapat Memperoleh Keuntungan Dilihat Dari Segi Kesejahteraan.

\begin{tabular}{lcc}
\hline \multicolumn{1}{c}{ Alasan } & Frekuensi (KK) & Persentase (\%) \\
\hline Transparansi harga yang jelas & 14 & 70 \\
$\begin{array}{l}\text { Mendapatkan informasi } \\
\text { menjadi kelompok tani }\end{array}$ & 6 & 30 \\
\hline Jumlah & 20 & 100 \\
\hline
\end{tabular}

Sumber : Petani Responden Desa Pondok Meja Tahun 2014

Pada Tabel 7 di atas dapat kita lihat persentase alasan yang melatarbelakangi persepsi petani dalam memasarkan bokar kepada koperasi. Petani responden mempersepsikan menjual bokar kepada koperasi bisa lebih menjamin pendapatan mereka lebih tinggi dilihat dari segi kesejahteraan, petani yang mempersepsikan menjual kepada koperasi lebih layak memberi kesejahteraan mereka karena koperasi adalah kelompok petani yang mandiri yang mengelola sendiri dari usahatani sampai dengan 
memasarkan dengan kualitas bokar yang baik dengan harga yang lebih tinggi, selain itu koperasi membentuk kelompok tani untuk membentuk kegiatan rutin setiap bulannya dengan tujuan belajar berusahatani yang baik sekaligus silaturahmi, ini juga yang membuat kenyamanan petani terhadap koperasi.

Para petani responden rata-rata menyatakan dua alasan yang sama disebutkan pada Tabel 7 yaitu yang pertama adalah, mereka telah percaya kepada koperasi karena koperasi lebih terbuka dalam transparansi harga tidak ada menipu dan merugikan petani, ini memberi kenyamanan petani dalam menjual bokarnya kepada koperasi dari aspek-aspek sosial terjamin kesejahteraannya. Kemudian yang kedua alasan yang melatarbelakangi petani mempersepsikan koperasi dapat menjamin kesejahteraan mereka yaitu petani dapat berkelompok untuk mendapat informasi-informasi dari PPL ataupun ketua koperasi mengenai budidaya karet.

Pada dasarnya persepsi petani dalam aspek sosial atau dalam penelitian ini adalah segi kesejahteraan adalah kenyamanan dalam pelayanan atau kedekatan khusus kepada petani tersebut. Dari segi untung rugi, koperasi merupakan yang lebih menguntungkan dalam harga bokar dengan selisih harga yang cukup jauh sekitar 2-3 ribu rupiah per kilonya. Tetapi dengan ketentuan dan syarat yang ditetapkan oleh koperasi, produksi bokar harus baik, mempunyai kadar karet kering yang baik sekitar $60 \%$, saran dengan ketebalan sleb bokar yaitu $5-10 \mathrm{~cm}$, dan direkomendasi menggunakan deorub agar bokar tidak bau. Sedangkan pedagang pengumpul tidak menuntut syarat bokar yang akan dibelinya, kapan saja mereka datang membeli tanpa harus petani yang mengantar. Kekurangan pada pedagang pengumpul yaitu pada harga bokar yang dibelinya jauh lebih rendah dibandingkan harga pada koperasi, permainan timbangan yang cepat dan tidak pasti serta hitungan berat kotor yang ditetapkan oleh pedagang pengumpul istilahnya pada petani yaitu basi yang merugikan petani.

\section{Implikasi Penelitian}

Pentingnya melakukan penelitian ini adalah untuk mengetahui persepsi petani dalam memasarkan bokar di Desa Pondok Meja Kecamatan Mestong Kabupaten Muaro Jambi. Dengan diketahuinya hal tersebut, diharapkan dapat menjadi masukan terhadap langkah-langkah yang perlu diambil oleh petani lainnya dalam melakukan usahataninya, selain itu agar dapat menjadi pertimbangan bagi kebijakan pemerintah dalam mengambil kebijakan yang berkaitan dengan pengembangan usahatani perkebunan karet yang ada di Desa Pondok Meja Kecamatan Mestong Kabupaten Muaro Jambi.

Penelitian yang telah dilakukan ini memperjelas bahwa persepsi petani dalam memasarkan bokar cukup beragam ditinjau dari dua aspek yang diteliti, diantaranya segi untung rugi atau aspek ekonomi dan segi kesejahteraan atau aspek sosial. Dengan berbagai persepsi yang muncul dapat dilihat terdapat persepsi dominan namun tidak mengesampingkan semua persepsi yang ada dengan berbagai alasan yang disampaikan petani tersebut. Sehingga, dapat dilihat bahwa pada saat ini dengan berbagai alasan yang ada persepsi petani dalam memasarkan bokar dari aspek yang berbeda memunculkan persepsi yang berbeda pula dari tiap-tiap aspek yang diteliti.

Keragaman persepsi tentang pemasaran bokar yang diperoleh petani dapat memberikan gambaran kedepannya usahatani karet dan hal-hal apa saja yang perlu dilakukan agar produksi dan harga nya baik. Dari hasil penelitian ini persepsi yang diperoleh dari responden, dapat diketahui keberlangsungan kesejahteraan petani kedepannya. 


\section{KESIMPULAN}

Berdasarkan hasil penelitian yang dilakukan di Desa Pondok Meja dapat disimpulkan sebagai berikut :

1. Dari segi untung rugi diperoleh bahwa sebagian petani yang menjadi responden mempersepsikan bahwa memasarkan bokar lebih menguntungkan dan memberi pendapatan lebih bagi mereka.

2. Dari segi kesejahteraan sebagian besar petani responden mempersepsikan memasarkan bokarnya kepada pedagang masih bisa menguntungkan. Persepsi Petani menyatakan bahwa dalam memasarkan bokar kepada pedagang pengumpul lebih mudah dan cepat.

3. Persepsi petani dalam memasarkan bokar dari berbagai aspek yang telah diteliti memperlihatkan bahwa persepsi petani cendrung lebih tinggi terhadap pedagang pengumpul. Keberadaan koperasi di Desa Pondok Meja tidak sepenuhnya merubah persepsi petani kepada pedagang pengumpul.

\section{UCAPAN TERIMAKASIH}

Terima kasih kepada Bapak Kepala dan Sekretaris Desa Pondok Meja, Bapak Ketua Kelompok Tani Budi Mulyo Desa Pondok Meja, Ibu PPL Perkebunan Desa Pondok Meja serta masyarakat yang bersedia memberikan keterangan untuk keperluan data penelitian. Terima kasih kepada Staf Dinas Perkebunan Provinsi Jambi, Dinas Perkebunan Kabupaten Muaro Jambi, Balai Penyuluhan Pertanian Kecamatan Mestong Jaluko dan Badan Pusat Statistik Provinsi Jambi yang telah memberikan literatur berupa bantuan data sekunder.

\section{DAFTAR PUSTAKA}

Abdul Rahman, Agus. 2013. Psikologi Sosial. PT Raja Grafindo Persada. Jakarta.

Balai Penyuluhan Pertanian. 2013. Data Base Perkebunan Kecamatan Mestong Tahun 2013. Jambi

Dinas Perkebunan Provinsi Jambi. 2013. Database Perkebunan Provinsi Jambi 20082013. Jambi

Kotler. 2002. Manajemen Pemasaran. PT. Indeks. Jakarta

Monografi Desa Pondok Meja. 2013. Desa Pondok Meja

Nazir, Moh. 2005. Metode Penelitian. LP3ES. Jakarta.

http://Psikomedia 2011.ac.id (diakses 15 Desember 2013)

Ridwan dan Akdon. 2008. Rumus dan Data Dalam Analisis Statistika. Alfabeta. Bandung. Sarwono. 2002. Psikologi sosial. AMUS. Yogyakarta

Singarimbun dan Effendi. 1995. Metode Penelitian Survei. LP3ES. Jakarta. 
Sunarto. 2003. Manajemen Pemasaran. AMUS. Yogyakarta

Thoha, Mitfah. 2004. Perilaku Organisasi (Konsep Dasar dan Aplikasinya). PT. Grafindo Persada. Jakarta.

Van Den Ban. A.W dan H.S. Hawkins, 2008. Penyuluhan Pertanian. Kanisus. Jogjakarta

Wahyuni. 2004. Koperasi.Ghalia Indonesia Jakarta. 